\title{
InTRODUCTION - Aspects OF THE GRAMMATIZATION OF THE CHINESE LANGUAGE
}

\author{
Tommaso Pellin \\ University of Bergamo, Bergamo, Italy
}

\section{INTRODUCTION}

In treating the language grammatically, some difficulty occurred: the Chinese have in reality no ideas of grammar corresponding with ours; and while the Sungskrit language abounds with grammatical works, the author has not been able to obtain the least idea of any treatise of this nature in the Chinese language.

(Marshman 1814: vi)

The author of the passage hereabove is Joshua Marshman (1768-1837), an English Protestant missionary to India who in 1814 published Clavis Sinica, a work on the Chinese language, including a presentation of the elements of Chinese grammar. Marshman was, undoubtedly, a pioneer of the study of Chinese grammar: his Clavis Sinica was one of the earliest grammars of Chinese and his research provided a very deep insight into the matter. Therefore, he is usually included among the scholars who contributed most to the development of studies of Chinese grammar. Yet from his words it can be assumed that he had no knowledge of native Chinese grammar studies and therefore, as far as this linguistic branch was concerned, he flatly dismissed Chinese traditional linguistic research: grammar studies, as Marshman puts it, simply do not exist in China.

While in 17th and 18th century essays on the Chinese language, written by European missionaries, Chinese was described as radically diverse, diametrically opposed $^{1}$, and the nature of grammatical studies in traditional China was not a matter of debate ${ }^{2}$, the cliché of the absence of grammar studies in China began to

1 See the quotation of Matteo Ricci in Di Toro's contribution in this issue, but also the first "Advertencia" by Francisco Varo in Varo 2000, p. 17.

2 In truth, there were some Western missionaries who were well aware that Chinese traditional linguistics did possess a few notions seemingly belonging to the realm of grammar, for instance Joseph De Prémare in his Notitia Linguae Sinicae, written around 1720. 
take shape and spread among sinologists and non-sinologists right from the beginning of the 19th century. The history of this cliché was discussed at length by several scholars ${ }^{3}$; it seems though that no one has ever proposed that such a stereotype might be the ideological basis for what, according to Sylvain Auroux's 1992 (Auroux 1992, p. 28) seminal theory, might well be considered as an instance of grammatization. Auroux himself was wary about including Chinese among the languages of the world which suffered grammatization, a wide process begun after the Renaissance in Europe and spread also outside it, by which several languages were supplied with linguistic tools such as dictionaries and grammars (see Auroux 1994, p. 109).

Auroux adopts a broad concept of grammar study for his speculation; it usually consists of a categorization of units, examples and rules to build linguistic acts (ibid., p. 110). According to such list, it is rather problematic to maintain that Chinese traditional linguistic description was grammatical However, it is possible to hypothesize that the grammatical description brought about both by the Catholic missionaries during the 17 th and 18 th centuries and by the Protestants during the 19th century fall within the concept of the extension of Latin grammar, examined by Fournier and Raby (2014). In the case of Chinese, it may be more apt to refer to it as a "partial grammatization": given that the tools of grammatization are dictionaries and grammars, Chinese linguistics was indeed well-equipped with a solid lexicographical tradition. Nonetheless, it was rather commonplace to consider implicitly or to state explicitly that it lacked grammar studies, paving the way for Westerners to fill this gap.

In fact, although it is patently clear that modern grammatical studies, or even grammatical studies on the whole, were prompted by contact with foreign languages, the case of grammatical analyses worded in Chinese was far more complex. Firstly, by the end of the 18th century, Chinese traditional linguistics had already developed a solid scholarly current regarding grammatical particles, the empty words: they are the main grammatical signposts for Chinese, together with word order. Secondly, Chinese scholars had started describing the grammatical features of the languages of some neighbouring countries, by means of their own grammatical notions. These two main grammatical traditions were the counterparts in a negotiation process. The negotiators were a multitude of agents: Chinese scholars, Chinese and Western merchants, Catholic and Protestant missionaries, Westerners and so on. Negotiation was conducted in a great number of languages: at that time there was not just one standard Chinese language but several languages, layered according to their stylistic register, as well as several local languages, not to mention foreign languages. This myriad of intersections gave rise to several ways 
with which the Chinese could think and talk about grammar. This abovementioned negotiation did not end when modern grammar studies were established: Western linguistics, even during the 20th century, was not instantaneously adopted by China, but Saussurism was subjected to much thoughtful meditation, as confirmed by Gao Mingkai's works (Romagnoli 2012).

At present, the knowledge of the history of Chinese linguistics and, in particular, of its grammatical research is far deeper than at Marshmann's time: even the nonsinologist scholars involved in the world's history of grammar studies are perfectly acquainted with the major branches of Chinese traditional linguistics, its main authors and their masterpieces. Several conferences have been held dealing with Chinese traditional linguistics and grammar studies as their main topics. The leading journals on the history of the world's linguistics have diffused the main facts about pre-modern grammatical thought in China (before the 20th century). As for the contribution of foreigners to the development of Chinese modern grammar, countless conferences and monographs have been dedicated in the last few years to the linguistic and grammatical research conducted by the most important Jesuit and Protestant missionaries in Eastern Asia, so they are also well known among experts in the history of grammar.

On the other hand, there were some Western missionaries who also wrote about Chinese and contributed to the development of modern grammatical thought in China, but were not acknowledged with the same fame; some Western and Chinese linguists, who wrote about foreign languages and thence supported the transformation and modernization of the Chinese grammatical set of notions, are not so widely known; native Chinese enquiries into foreign languages, which proved to be elements included in this partial grammatization process, are a seldom recounted matter of study.

In conclusion, modern Chinese grammar studies were shaped not only by the most famed authors and their great works, but also by less celebrated scholars, both Westerners and Chinese, with their little-known works. This thematic issue of Histoire Épistémologie Langage is dedicated to shedding light on some of them, in order to collect more data about the peculiar process of the grammatization of Chinese.

\section{Chinese traditional grammar studies}

China boasts one of most solid, well-developed and ancient traditions of language study (see for instance Auroux et al. 2000, p. 19-57). Xiăoxué 小學, the discipline which is usually acknowledged as traditional Chinese linguistics, is usually divided into wénzìxué 文字學, the studies of the characters and their etymology; yinyùnxué 音䫓學, the studies of the phonology of words; xùngǔxué 訓詁學, the studies of the 
ancient texts and their commentaries. According to some histories of Chinese linguistics, the following similarities were proposed: wénzìxué may correspond with the study of the graphical form of the words, while yinyùnxué is the counterpart of phonology and xùngǔxué of semantics (see Hu 1987, p. 5-6; Gong 1997, p. 1). As shown by Hu Qiguang, the origins of Chinese grammar studies, i.e. wénfăxué 文法學, are rooted in xùngǔxué; in fact, xiăoxué lacked a specific and systematic field of research into the grammatical structure of the language, let alone a term for it, until the 19th century.

With regard to xiăoxué studies, the interest of linguists was aroused by the problem of the word classes: numerous attempts at analysing them were carried out throughout most of the history of Chinese linguistics, and their results are considered to be the most important "buds" of a systematic description of Chinese grammar. The main class of words that Chinese traditional grammatical studies have created is that of the so-called grammatical particles, named zhùcí 助辭 or yǔzhù 語助. These are specialized particles, which include verbal particles (those which express verb aspect), modal particles (those which express interrogation and also have the function of indicating the end or the beginning of the sentence), but also pronouns, adverbs, conjunctions, prepositions and interjections. The class of grammatical particles, also known as $x \bar{u} z i$ 虛字 'empty words', together with its counterpart, the content words (shizi 實字), are the only grammatical category genuinely created by Chinese linguistics which give at least some hints of the concepts of the structure of the sentence in the mind of Chinese traditional linguists (see Hé 1995, p. 279). Liú Qí's Zhùzì biànlüè 助字讋略 [Compendium on particles] (1711) and Wáng Yǔnzhī’s Jingzhuàn shici 經傳釋詞 [Explanation of the particles in the Classics and in their commentaries] (1789) are among the last and most mature works of this tradition of studies. Mariarosaria Gianninoto discusses the partial translation by the French sinologist Stanislas Julien of Wáng Y̌nzhī’s work as a witness to the relevance of the traditional approach to Chinese grammatical particles.

\section{Chinese studies of languages of Asian people}

Apart from xiăoxué, the Chinese government supported a more practical activity of language studies, whose target was the languages of the neighbouring countries. From their earliest stages in antiquity up to the 19th century, the relationships between the Chinese and their neighbouring populations have always been very intense; throughout history, the imperial institutions have always set up special offices and agencies for the relations with foreign countries and nations, where translators and interpreters were hired for managing foreign delegations during their official visits; very seldom, though, did these agencies also have the task of training translators or interpreters. 
It is known that it was only in 1289 that the first government school for teaching foreign languages was founded: it was the Huíhuí guózixué 回回國子學 (raised to the status of imperial college in 1314). This was a school where the Persian language was taught for diplomatic relations. In 1407, the Sìyíguăn 四夷館 [Institute for foreign languages] was founded: at first it was a mere translation agency, but in 1426 courses of the most important foreign languages of that time, including Tibetan, Hindi, Thai, Mongol, Arab and Burmese, were started (Fù 1984, p. 7-8). This institute, which under the Qīng dynasty changed its name to Siỳguăn 四譯館 [Institute for translations] existed until 1748, when it was merged with the Huitóngguăn 會同館, a Míng institute devoted to managing interpretation (Nappi 2015, p. 219). During the last years of the Siyìguăn, between 1729 and 1744, another institute for the formation of translators and interpreters was founded, the Xīyángguăn 西洋館 [Institute for Western languages], which was run by the Jesuits for the purpose of teaching Latin and some Russian, after the intensification of the relationships with the Russian Empire (Gianninoto 2005, p. 606). In 1708 one more school for foreign languages was founded: the Éluósī wénguăn 俄羅斯文館 [Institute for Russian language], which dedicated most of its time to teaching Russian to future personnel involved in relations with the Czarist empire (Fù 1984, p. 10). More than one and a half centuries later, in 1862, the Éluósī wénguăn was incorporated into the newly-established Jīngshī Tóngwénguăn 京師同文館 [Institute for foreign languages in Beijing].

During the Míng and Qing dynasties, it is known that at the Siỳ̀guăn, at the Huitóngguăn and at the institute formed by their merger, the Huitóng Sìyìgaăn 會 同四譯舘, several bilingual glossaries were compiled, at least one for every linguistic department of which these institutes consisted; glossaries were published for Mongol, Persian, Tibetan, Uyghur, Burmese and many more Asian languages. They are collectively known as Huáyí yìy̌ 華夷譯語 [Glossaries in Chinese and foreign languages], even though strictly speaking the first Huáyi yìǔ is the Chinese-Mongol glossary, and several editions were issued of many of them over time (Yong and Peng 2008, p. 391-395). In the tradition of Huáyí yìŭ, some deeper analyses were proposed of the grammar of these languages, on the basis of their peculiar grammatical terminology. Takashi Takekoshi illustrates the patterns of description of Manchu languages in a number of textbooks stemming from this tradition: in these textbooks the particular features of this Altaic language are dealt with only by means of the Chinese traditional linguistic notion and according to the traditional linguistic delineation. 
4 Grammar studies of Chinese dialects AND of FOREIGN LANGUAGES IN 19TH CENTURY

It is widely known that from the beginning of the 17th century up to the 19th century, a number of Europeans, mainly Jesuit missionaries, wrote several grammars of the Chinese language, either in Latin or in European languages. As Anna Di Toro recounts, the Russian missionary Iakinf Bičurin (1777-1853), in his Kitajskaja grammatika (1831), describes in detail the major linguistic works previously written up to his time, before introducing his own version of the Chinese grammar. The target of the studies of these missionaries were more often either the colloquial koine of the members of the imperial bureacracy or sometimes the written language of literary classics too.

Given the expansion of their presence in the Chinese territory, in particular after the second Opium war (1860), Protestant missionaries started to write teaching materials, including grammar books, on different Chinese dialects. Luisa Paternicò lays out the development of the grammar studies on Cantonese from simple descriptions of mid-19th century up to the mature grammatical essays of the first decades of the 20th century, which contributed ante litteram at debunking the myth of "one universal Chinese grammar".

Western languages were dealt with in a small number of texts as well. For instance, Catholic missionaries compiled some simple Latin grammar books (such as Joaquim Afonso Gonçalves' Grammatica latina, published in 1828, or Angelo Zottoli's Emmanuelis Alvarez institutio grammatica ad sinenses alumnus accomodata, published in 1859) for the students of their colleges. English and American missionaries, on the other hand, published some grammar books on the English language: Pellin presents the features of the English grammar books of two of the most influential sinologists of the 19th century, Robert Morrison (17821834) and William Lobscheid (1822-1893). Both Latin and English grammar books were not only written in foreign languages but were coupled with a Chinese translation, often provided with a tentative translation of grammatical terminology. Despite the elementary level of the texts under consideration, the introduction of Western grammatical theoretical sets directly into the Chinese language was, undoubtedly, a further step in the process of grammatization of Chinese.

These grammar books of foreign languages written by Western missionaries were the blueprint for the first Chinese scholars who wrote the earliest native grammar texts completely in Chinese; in particular, the terminology provided by Western grammar books was sometimes borrowed by the Chinese scholars, at other times it was not. Pellin shows that Cáo Xiāng’s (1844-1923) Yìngzì rùmén 英字入 門 [Introduction to English] (1874) and Wāng Fèngzăo’s (1851-1918) Yīngwén jǔyú 英文舉隅 [Examples of English] (1878) appear to be the first texts in which 
Chinese authors tried to apply the notions of Western grammar to Chinese on their own; moreover, the introduction and establishment of some form of terminology was another stage of Chinese grammatization.

\section{Modern Chinese grammar STUdies AND THEIR RElationship With}

\section{WESTERN GRAMMAR STUDIES}

For Chinese linguistics the 20th century saw the foundation of its modern grammar studies, embodied by the publication of Mă Jiànzhōng's Măshì wéntōng. Immediately after its publication, a series of new Chinese grammars was published; all of them expressed harsh criticism against the Măshì wéntōng, in particular regarding its adherence to Western (Latin) theoretical structure, which was considered too narrow and unfit to describe Chinese properly ${ }^{4}$. The new trends in Chinese grammar studies found their first mature synthesis in Lí Jǐnxī’s 黎錦熙 (1890-1973) Xìnzhù guóyǔ wénfă 新著國語文法 [New grammar of the national grammar] (1924). Notwithstanding the fact that by that time modern grammar had definitely been founded, its relationship with contemporary Western grammar studies was fraught with suspicion and distinctions. Romagnoli provides an instance of this troubled relationship by following the recent development of the debate about Ferdinand de De Saussure in China. In particular, Romagnoli shows how, whereas some Chinese scholars are now fully aware of the issues related to the Saussurean sources, others still provide an ideological reading of the Swiss linguist's work reflecting a research approach anchored in the past.

\section{BIBLIOGRAPHY}

Auroux, Sylvain, 1992. "Introduction. Le processus de grammatisation et ses enjeux", Auroux, Sylvain (ed.), Histoire des idées linguistiques, t. 2, Liège, Mardaga, 11-64.

- 1994. La révolution technologique de la grammatisation, Liège, Mardaga.

Auroux, Sylvain, Koerner, E. F. K., Niederehe, Hans-Josef and Versteegh, Kees (eds), 2000. History of the Language Sciences Volume 1, Berlin, de Gruyter.

Fournier, Jean-Marie et Raby, Valérie, 2014. "Retour sur la grammatisation: l'extension de la grammaire latine et la description des langues vulgaires", Archaimbault, Sylvie, Fournier, Jean-Marie and Raby, Valérie (eds.), Penser l'histoire des savoirs linguistiques. Hommage à Sylvain Auroux, Lyon, ENS Éditions, 337-350.

Fù, Kè 付克, 1984. Zhōngguó wàiyǔ jiàoyùshì 中國外語教育史 [History of foreign languages teaching in China], Shanghai, Shanghai Waiyu Jiaoyu Chubanshe.

Gianninoto, Mariarosaria, 2005. "Le grammatiche cinesi di latino nel diciannovesimo e ventesimo secolo", Scarpari, Maurizio and Lippiello, Tiziana (eds). Caro Maestro.. scritti in onore di Lionello Lanciotti per l'ottantesimo compleanno, Venezia, Cafoscarina, 605-620.

4 A huge debate has been going on about the value of Măshì wéntōng since its publication; see among others Gōng (1997), p. 46 ff.; for the development of the first years of the 20th century see among others Pellin (2011). 
Gōng, Qiānyán 龔千炎, 1997. Zhōngguó yǔfăxuéshǐ 中國語法學史 [History of Chinese grammar studies], Beijing, Yuwen Chubanshe.

Hé, Jiǔyíng 何九盈, 1995. Zhōngguó gǔdài yǔyánxuéshǐ 中國古代語言學史 [History of ancient Chinese linguistics], Guangzhou, Guangdong Jiaoyu Chubanshe.

Hú, Qíguāng 胡奇光, 1987. Zhōngguó xiǎoxuésh ̀̌ 中国小学史 [History of traditional Chinese linguistics], Shanghai, Shanghai Renmin Chubanshe.

Liu, Lydia, 2004. The Clash of Empires: The Invention of China in Modern World Making, Cambridge, Harvard University Press.

Marshman, Joshua, 1814. Elements of Chinese Grammar,: With a Preliminary Dissertation on the Characters, and the Colloquial Medium of the Chinese, and an Appendix Containing the Ta-Hyoh of Confucius with a Translation, Serampore, Mission Press.

McDonald, Edward, 2018. "The Challenge of a 'Lacking' Language: the Historical Development of Chinese Grammatics", Chinese Language and Discourse 8, 244-265.

Nappi, Carla, 2015. "Full. Empty. Stop. Go.: Translating Miscellany in Early Modern China", Newman, Karen and Tylus, Jane (eds), Early Modern Cultures of Translation, Philadelphia, University of Pennsylvania Press, 206-220.

Pellin, Tommaso, 2011. "The Sweet Revolutionaries: the Chinese Revolution in Grammar Studies and Henry Sweet". Language and History, 35-57.

Romagnoli, Chiara, 2012. The interpretation of Saussure's Cours de linguistique générale in China, Roma, Nuova Cultura.

Saussy, Haun, 1999. "Always multiple translation, or, How the Chinese language lost its grammar", Liu, Lydia (ed.), Tokens of exchange: the problem of translation in global circulations, Durham, Duke University Press, 107-123.

Varo, Francisco, 2000. Francisco Varo's Grammar of the Mandarin Language (1703): An English Translation of 'Arte de la lengua Mandarina', Translation and notes by Coblin, South W. and Levi, Joseph A., Amsterdam/Philadelphia, John Benjamins.

Yong, Heming and Peng, Jing, 2008. Chinese Lexicography : A History from 1046 BC to AD 1911, Oxford, Oxford University Press. 